\title{
Recent Advances in the (Molecular) Phylogeny of Vertebrates
}

\author{
Axel Meyer \\ Department of Biology, University of Konstanz, 78457 Konstanz, Germany; \\ email:axel.meyer@uni-konstanz.de \\ Rafael Zardoya \\ Museo Nacional de Ciencias Naturales, CSIC, José Gutiérrez Abascal, 2, 28006 Madrid, \\ Spain; email:rafaz@mncn.csic.es
}

Key Words molecular systematics, Agnatha, Actinopterygii, Sarcopterygii, Tetrapoda

Abstract The analysis of molecular phylogenetic data has advanced the knowledge of the relationships among the major groups of living vertebrates. Whereas the molecular hypotheses generally agree with traditional morphology-based systematics, they sometimes contradict them. We review the major controversies in vertebrate phylogenetics and the contribution of molecular phylogenetic data to their resolution: $(a)$ the mono-paraphyly of cyclostomes, $(b)$ the relationships among the major groups of rayfinned fish, $(c)$ the identity of the living sistergroup of tetrapods, $(d)$ the relationships among the living orders of amphibians, $(e)$ the phylogeny of amniotes with particular emphasis on the position of turtles as diapsids, $(f)$ ordinal relationships among birds, and $(g)$ the radiation of mammals with specific attention to the phylogenetic relationships among the monotremes, marsupial, and placental mammals. We present a discussion of limitations of currently used molecular markers and phylogenetic methods as well as make recommendations for future approaches and sets of marker genes.

\section{INTRODUCTION}

All studies in comparative biology depend upon robust phylogenetic frameworks. Although the history of vertebrates is relatively well documented in the fossil record (Carroll 1997), the answers to several major issues in vertebrate systematics are still debated among systematists. Often debates arise because of large gaps in the fossil record, rapid lineage diversification, and highly derived morphologies of the extant lineages that complicate the reconstruction of evolutionary events and the establishment of solidly supported phylogenetic relationships. Traditional approaches to studying the phylogeny of vertebrates such as paleontological and comparative morphological methods were augmented by the advent of molecular sequence data about a decade ago. Here we review the contribution of molecular 


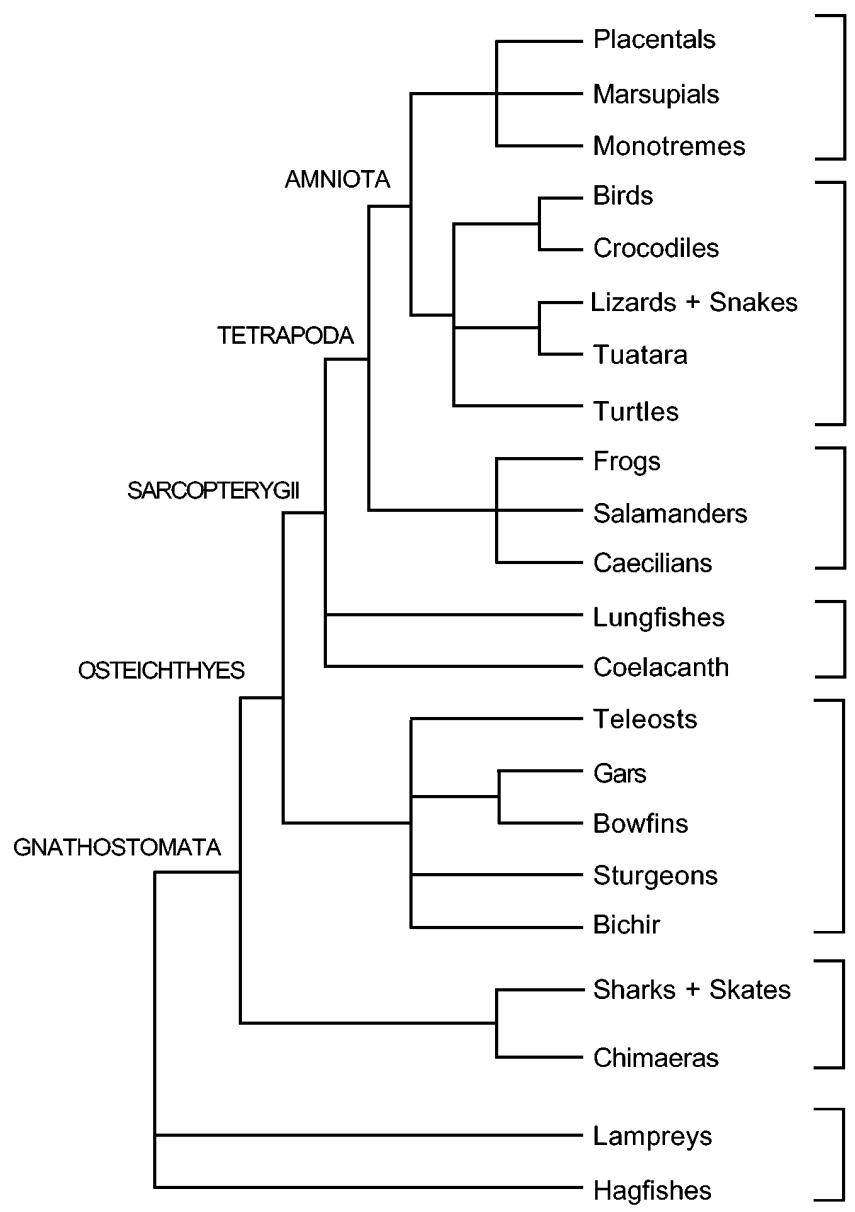

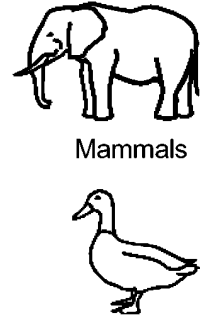

Reptiles (including birds)



Amphibians
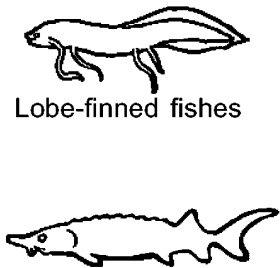

Ray-finned fishes

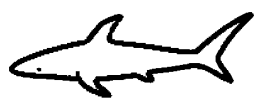

Cartilaginous fishes

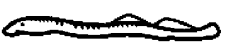

Agnathans

Figure 1 Phylogenetic hypothesis for the major lineages of vertebrates based on morphological, paleontological, and molecular evidence. Disputed relationships are depicted as polytomies.

systematics to the major unresolved questions (polytomies in Figure 1 in the phylogeny of extant vertebrates) (Benton 1990).

One of the first major innovations in the evolution of vertebrates was the origin of jaws in the Cambrian, 540-505 million years ago (mya) (Carroll 1988). Accordingly, vertebrates have been traditionally classified into Agnatha or cyclostomes (hagfishes and lampreys) and Gnathostomata (the jawed vertebrates) (Figure 1). The mono- or paraphyly of living agnathans is the first controversy that we will discuss. Among jawed vertebrates, the major division, based largely on the composition of the skeleton, is between the Chondrichthyes (cartilaginous fishes) 
and the Osteichthyes (bony fishes) (Figure 1). Bony fishes are further divided into Actinopterygii (ray-finned fishes) and Sarcopterygii (lobe-finned fishes + tetrapods) (Figure 1). The origin and the phylogeny of the major lineages of rayfinned fishes are still subject to debate (Figure 1). The transition to life on land dates back to the Devonian, 408-360 mya (Carroll 1988), and the relationships of the living lobe-finned fishes (lungfishes and coelacanths) to the tetrapods is still actively discussed (Figure 1).

The first lineage of tetrapods that branched off is the Lissamphibia (caecilians, salamanders, and frogs). There is controversy surrounding both their origin(s) in the Permian, 280-248 mya (Carroll 1988), and their interrelationships (Figure 1). One of the major evolutionary novelties of the tetrapods was the origin of the amniote egg that permitted the permanent independence from water for reproduction and ultimately, the colonization of land. Living amniotes are mammals and reptiles (turtles, lizards and snakes, crocodiles and birds) (Figure 1). The origin of amniotes dates back to the Pennsylvanian, 325-280 mya (Carroll 1988). The amniotes have traditionally been divided into three groups based on the fenestration of their skulls. Anapsids (without holes in the skull) are represented by turtles, the diapsids (with two holes in the skull, at least initially) are the tuatara, snakes and lizards, crocodiles, and birds, and the mammals (with one hole in the skull) make up the synapsids. The relationships among the three lineages of amniotes are contended, particularly because of the uncertainty regarding the phylogenetic position of turtles (Figure 1). Molecular phylogenetic data recently shook up the traditional understanding of the ordinal relationships among the birds, as well as those of the placental mammals. This type of data also questioned the previous hypothesis of the evolutionary relationships among the three major groups of mammals, the monotremes, marsupials, and placental mammals (Figure 1).

In the following sections we will review, in some detail, each of the remaining major questions (polytomies in Figure 1) in the evolution of vertebrates. We will discuss the potential causes for the difficulty in resolving these questions, the status of the debate, and the specific contribution that molecular systematics has made to a resolution of these issues.

\section{MONOPHYLY OR PARAPHYLY OF AGNATHANS}

Fossils of the earliest vertebrates found in the Chengjiang Lagerstätte from the early Cambrian suggest that vertebrates are part of the Cambrian explosion (Shu et al. 2003). Unlike the chordate filter feeders that had and still have an almost exclusively sedentary or even sessile lifestyle, the earliest vertebrates used their newly evolved head, and sensory organs derived from neural crest tissues, to actively locate and feed on more macroscopic prey. The earliest vertebrates or agnathans were jawless, and reached their peak of species richness in the Devonian. Only a small number of species of hagfishes (Mixiniformes, 43 species) and lampreys (Petromyzontiformes, 41 species) represent the two extant lineages of agnathans. 
Jawless vertebrates clearly are a paraphyletic group, at least when extinct lineages are taken into consideration (Janvier 1996). It seems well established that some of the extinct lineages of the Ostracodermata, in particular the Osteostraci, are more closely related to the jawed-vertebrates than they are to other agnathans (Shu et al. 2003). However, whether or not the living hagfishes and lampreys form a monophyletic group, traditionally called the round mouths or cyclostomes (Figure $2 A$ ), or whether they are paraphyletic, with the lampreys more closely related to the jawed vertebrates (Figure $2 B$ ), is still debated mostly among molecular phylogeneticists. Most paleontologists now strongly favor the paraphyly hypothesis for the living agnathans (Janvier 1996) (Figure 2B).

There are a number of important problems that adversely affect the solution of this problem both for paleontologists and molecular phylogeneticists (Mallat \& Sullivan 1998, Mallat et al. 2001, Zardoya \& Meyer 2001c). First, the only three surviving lineages of vertebrates (hagfishes, lampreys, and jawed vertebrates) appeared within a time window of less than 40 million years in the Cambrian (Janvier 1996). This allowed only a short time period for the accumulation of diagnostic synapomorphies (both morphological as well as molecular ones) but a long time period of independent evolution and the accumulation of many autapomorphies to overlay the possibly previously existing phylogenetic signal. Second, there are big gaps in the fossil record that can be partly explained by the lack of bone in hagfish and lampreys. Further problems arise because of the rather "featureless" morphology of the earliest vertebrates (Shu et al. 2003).

The traditional classification of vertebrates uniting hagfishes and lampreys as cyclostomes (Figure $2 A$ ) was supported by a number of morphological traits including the presence of horny teeth, a respiratory velum, and a complex "tongue" apparatus (Delarbre et al. 2000). However, more recent morphological analyses found several apparently shared derived characters between lampreys and jawed vertebrates (Janvier 1981, 1996) (Figure 2B). This paraphyletic relationship is even more strongly supported by cladistic analyses of several recent fossil finds from the Chinese Lagerstätten (Shu et al. 1999, 2003).

Several molecular studies have addressed the question of the relationships of the living agnathan lineages to the gnathostomes. Phylogenetic analyses of the nuclear 18 S and 28S rRNA genes (Mallat \& Sullivan 1998, Mallat et al. 2001, Zardoya $\&$ Meyer 2001c) suggested a monophyletic cyclostome clade (Figure $2 A$ ) with a relatively high support [for the rest of the text we mean a bootstrap value over $70 \%$ (Zharkikh \& Li 1992)]. The analyses of several other nuclear loci also support the cyclostome hypothesis (Kuraku et al. 1999), and the most recent analyses of the largest data set so far (35 different nuclear markers) also came out in favor of the monophyly hypothesis (Takezaki et al. 2003). By contrast, phylogenetic analyses of mitochondrial protein-coding genes seem to support the paraphyly hypothesis, with lampreys as the closest living sistergroup to jawed vertebrates (Rasmussen et al. 1998) (Figure 2B). One of the crucial problems in the reconstruction of early vertebrate phylogeny using molecular data is that the hagfish branch is extremely long (Zardoya \& Meyer 2001c). This circumstance could artificially pull the highly divergent hagfish sequence toward the outgroup (Sanderson \& Shaffer 2002) and 


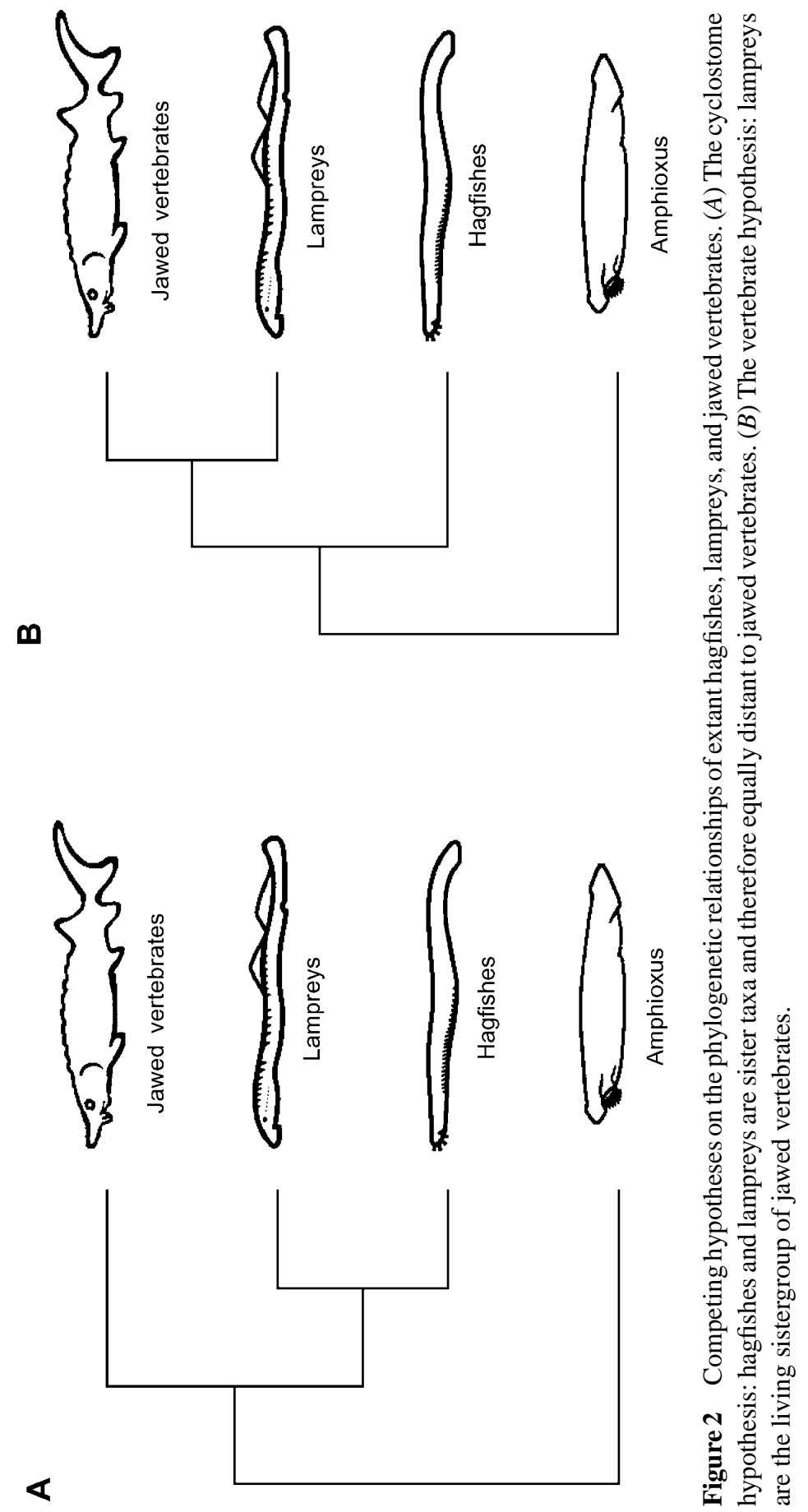


may explain the mitochondrial phylogeny (Rasmussen et al. 1998). More recent phylogenetic analyses using mitochondrial markers with a larger set of taxa provided support for both competing hypotheses depending on the method of phylogenetic inference (Delarbre et al. 2000). These results may suggest that this phylogenetic problem involves evolutionary divergences that go beyond the limits of resolution of mitochondrial genes (Takezaki \& Gojobori 1999, Zardoya \& Meyer 2001c).

Most paleontologists continue to support the paraphyly and most molecular systematists the monophyly hypothesis. Despite the fact that there are only two alternative hypotheses to consider, the phylogenetic relationships of hagfishes, lampreys, and jawed vertebrates still remain an undecided controversy in vertebrate systematics. It will require the analysis of larger (nuclear DNA) data sets with a denser taxon sampling in the lamprey and hagfish lineages that might divide the long branches and lead to more robustly supported phylogenetic hypotheses.

\section{PHYLOGENETIC RELATIONSHIPS OF ACTINOPTERYGIAN FISHES}

The origin of jaws, a key innovation that allowed gnathostomes to grasp large prey, was one of the major events in the history of vertebrates. This feature is likely related to the evolutionary success of both the cartilaginous fishes (Chondrichthyes: chimaeras, sharks + skates) and the bony fishes (Osteichthyes: ray-finned fishes, lobe-finned fishes + tetrapods). It is uncontested that Chondrichthyes are the sistergroup of the Osteichthyes (e.g., Carroll 1988) (Figure 3). Surprisingly, some recent molecular studies based on mitochondrial sequence data (Rasmussen \& Arnason 1999) recovered sharks as the sistergroup of teleosts (advanced ray-finned fishes) and suggested a derived position of Chondrichthyes in the pisicine tree. Further analyses showed that such unorthodox phylogenetic relationships were caused by noise (saturation) in the molecular data (Zardoya \& Meyer 2001c) and supported the traditional Chondrichthyes + Osteichthyes sistergroup relationship.

With more than 25,000 species (Eschmeyer 1998), ray-finned fishes (Actynopterygii) are the most speciose group of vertebrates. Ray-finned fishes date back to the early Devonian (Dialipina; Schultze \& Cumbaa 2001) and their diversity and number has since then increased steadily. In contrast to most other

Figure 3 Alternative hypotheses on the phylogeny of the basal lineages of the Actinopterygii (ray-finned fishes). (A) Polypteriformes (bichirs and reedfishes) and Acipenseriformes (sturgeons and paddlefishes) are sistergroup taxa (Chondrostei). Gars and bowfins are the sistergroup of teleosts (Neopterygii). (B) Acipenseriformes are the sistergroup of Neopterygii to the exclusion of Polypteriformes. (C) Polypteriformes are the sistergroup of a clade that includes the Acipenseriformes as the sistergroup of gars and bowfins to the exclusion of teleosts. Most recent molecular data favor this latest hypothesis. 

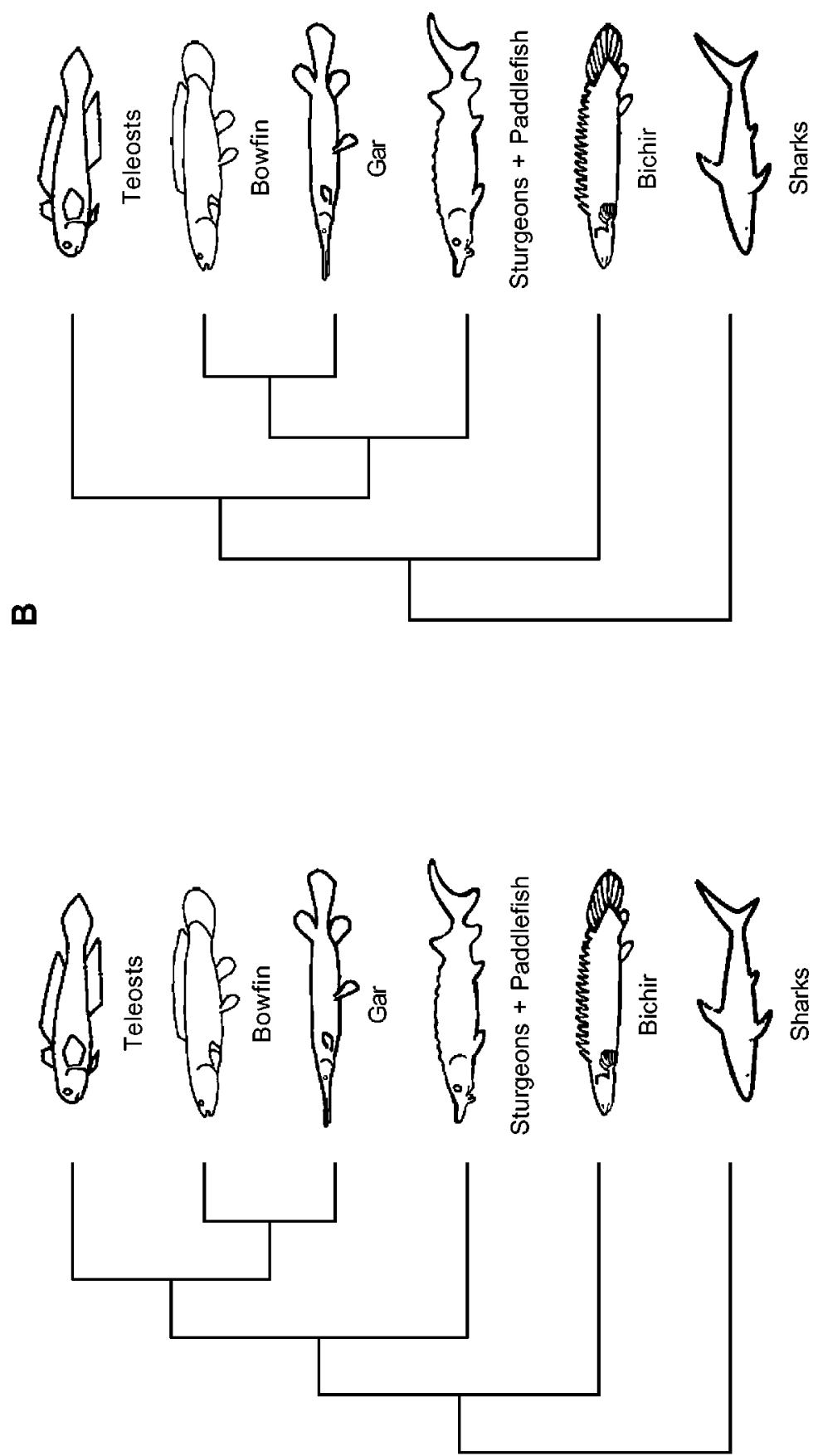

4 
groups of vertebrates, the known diversity of living ray-finned fishes exceeds that of known fossil taxa (Nelson 1994). Ray-finned fish have been traditionally divided into "lower" and "higher" actinopterygians (Gardiner \& Schaeffer 1989). The former, also referred to as Chondrostei, includes the Polypteriformes (bichirs and reedfishes) and Acipenseriformes (sturgeons and paddlefishes) (Nelson 1994). The more derived ray-finned fishes, the Neopterygii, include gars, bowfins, and the teleosts that make up more than $96 \%$ of all extant species of ray-finned fish (Nelson 1994) (Figure 3A).

Some lower actinopterygian relationships are uncertain (Grande \& Bemis 1996). Most paleontological and neontological workers place polypteriforms as the most basal lineage of ray-finned fishes (e.g., Gardiner \& Schaeffer 1989, Lauder \& Liem 1983) (Figures $3 B$ and $3 C$ ). However, because of their peculiar lobed fins, polyteriform fish had even been described as sarcopterygians (Huxley 1861) or classified into their own subclass, the Brachiopterygii (Bjerring 1985, Jessen 1973). All molecular studies bearing on this question agree that polypteriforms are the most basal lineage of the Actinopterygii (Inoue et al. 2003, Le et al. 1993, Noack et al. 1996, Venkatesh et al. 2001).

However, the relative phylogenetic position of Acipenseriformes is debated (Figures $3 B$ and $3 C$ ). Most morphological studies place sturgeons and paddlefishes as the closest living sistergroup of the Neopterygii (Grande \& Bemis 1996, Nelson 1969; but see Nelson 1994). This phylogenetic position was further supported by 28S rDNA sequence data (Le et al. 1993) (Figure 3B). However, recent molecular studies based on complete mitochondrial genome (Inoue et al. 2003) and nuclear RAG1 (Venkatesh et al. 2001) sequence data favor a close relationship of acipenseriforms to gars and bowfins to the exclusion of teleosts (Figure 3C). There is also no consensus on the identity of the closest living sistergroup of teleosts (Arratia 2001). Competing morphological hypotheses suggest that bowfins (Gardiner et al. 1996, Grande \& Bemis 1996, Patterson 1973), gars (Olsen 1984), or both bowfins + gars (Holostei; Jessen 1973, Nelson 1969) are the closest relative(s) of teleosts. As mentioned above, recent molecular studies (Inoue et al. 2003, Venkatesh et al. 2001) support that acipenseriforms, bowfins, and gars form a monophyletic group, and therefore, that they are equally related to teleosts (Figure 3C).

Because of the large number of taxa involved (there are up to 38 recognized orders of teleosts; Nelson 1994), and the lack of morphological synapomorphies, the higher-level phylogenetic relationships of teleosts have been difficult to resolve (Greenwood et al. 1966, Nelson 1989). An impressive effort was made in a recent study to solve this question by sequencing and analyzing the complete mitochondrial sequence of 100 higher teleosts (Miya et al. 2003). Interestingly, the resulting molecular phylogeny strongly rejected the monophyly of all major groups above the ordinal level as currently defined (Greenwood et al. 1966). Future phylogenetic analyses of nuclear sequences (e.g., from the RAG-1 gene) will be key in resolving the apparent inconsistency between morphological hypotheses and mitochondrial evidence. 


\section{THE ORIGIN OF TETRAPODS}

The origin of land vertebrates dates back to the Devonian (408-360 mya) (Carroll 1988). The conquest of land by vertebrates was an important evolutionary event that involved morphological, physiological, and behavioral innovations (Clack 2002). A strong paleontological record indicates that early tetrapods evolved from lobe-finned fishes, and recent fossil discoveries have shown that a particular group, the panderichthyids, are the closest relatives of land vertebrates (Ahlberg \& Johanson 1998; Ahlberg et al. 1996; Clack 2000, 2002; Cloutier \& Ahlberg 1996; Vorobyeva \& Schultze 1991). The sistergroup of panderichthyids plus tetrapods are osteolepiforms (Ahlberg \& Johanson 1998, Clack 2000, Cloutier \& Ahlberg 1996). Dipnomorpha and Actinistia make up the other two major groups of lobe-finned fishes. Dipnomorphs include the extinct porolepiforms, and the air-breathing extant lungfishes (Dipnoi). Actinistia or coelacanths were a highly successful group of lobe-finned fishes during the Devonian that now are represented by only two surviving species (Latimeria chalumnae and L. menadoensis). Although most recent morphological and paleontological evidence support lungfishes as the closest living sistergroup of tetrapods (Ahlberg \& Johanson 1998, Cloutier \& Ahlberg 1996) (Figure $4 A$ ), until recently there was no general agreement regarding which group of living lobe-finned fishes, the Actinistia or the Dipnomorpha, is the one most closely related to the tetrapod lineage (Meyer 1995, Zardoya \& Meyer 1997b). There is still disagreement among paleontologists about the homology of some important characters (e.g., the choanae) (Cloutier \& Ahlberg 1996) and relevant fossils of intermediate forms connecting the three groups still await discovery.

Significant amounts of molecular phylogenetic data from the living sarcopterygian lineages, lungfishes, coelacanths, and tetrapods have been collected to address this phylogenetic problem. There are three competing phylogenetic hypotheses regarding the relationships among the living lineages of sarcopterygians: lungfishes as the sistergroup to tetrapods (Figure $4 A$ ), the coelacanth as the sistergroup of tetrapods (Figure $4 B$ ), and lungfish and coelacanth as a monophyletic sistergroup to tetrapods (Figure $4 C$ ). The first molecular data set that supported lungfishes as closest living relatives of tetrapods (Figure $4 A$ ) was based on two fragments of the mitochondrial 12S rRNA and cytochrome $b$ genes (Meyer \& Wilson 1990). Further support for this hypothesis was obtained from the phylogenetic analysis of complete 12S and 16S rRNA mitochondrial genes (Hedges et al. 1993). However, a reanalysis of this data set with more taxa resulted in an unresolved lungfish + coelacanth + tetrapod trichotomy (Zardoya \& Meyer 1997a, Zardoya et al. 1998). Phylogenetic analyses of a data set that combined all mitochondrial proteincoding genes identified lungfishes as the sistergroup of tetrapods (Zardoya \& Meyer 1997a, Zardoya et al. 1998) (Figure 4A). However, this data set could not statistically reject a lungfish + coelacanth clade (Figure $4 C$ ) but could reject the coelacanth + tetrapod hypothesis (Figure $4 B$ ). Phylogenetic analyses of a data set that combined all mitochondrial tRNA genes supported a close relationship between lungfishes and the coelacanth (Zardoya \& Meyer 1997a, Zardoya et al. 





1998) (Figure 4C). When the mitochondrial protein-coding gene data set was combined with the rest of the mitochondrially encoded (rRNA and tRNA) genes, it also supported lungfishes as the closest living sistergroup of tetrapods (Zardoya et al. 1998). Phylogenetic analyses of nuclear 28S rRNA gene sequences favored a lungfish + coelacanth grouping (Zardoya \& Meyer 1996) (Figure 4C). The phylogenetic analyses of the combined mitochondrial and 28S rRNA nuclear data sets were not entirely conclusive. Depending on the method of phylogenetic inference used, both a lungfish + tetrapod (Figure $4 A$ ) or a lungfish + coelacanth clade (Figure 4C) were supported (Zardoya et al. 1998). The coelacanth + tetrapod hypothesis (Figure $4 B$ ) received the least support in all phylogenetic analyses of any molecular data. Recent phylogenetic analyses of a nuclear gene, the myelin DM20 also supported lungfishes as the sistergroup of tetrapods (Tohyama et al. 2000) (Figure $4 A$ ). The lungfish + tetrapod clade is also supported by a single deletion in the amino acid sequence of a nuclear-encoded gene RAG2 that is shared by lungfishes and tetrapods (Venkatesh et al. 2001). Overall, most molecular and morphological evidence supports lungfishes as the closest living sistergroup of tetrapods (Figure $4 A$ ) and, albeit cautiously, we conclude that this phylogenetic issue has been solved.

\section{PHYLOGENETIC RELATIONSHIPS AMONG MODERN AMPHIBIANS}

Most researchers agree that modern amphibians (Lissamphibia) form a monophyletic group that appeared in the Permian (280-248 mya) (Duellman \& Trueb 1994, Parsons \& Williams 1963, Szarski 1962). Among paleontologists it is still debated whether the extinct temnospondyls (e.g., Panchen \& Smithson 1987, Trueb \& Cloutier 1991) or the extinct lepospondyls (Carroll 1995, Laurin 1998, Laurin \& Reisz 1997) are their sistergroup. Furthermore, there is no general agreement regarding the phylogenetic relationships among the three living orders of amphibians, the Gymnophiona (caecilians), Caudata (salamanders), and Anura (frogs). Most morphological and paleontological studies suggest that salamanders are the closest relatives of frogs (and form the clade Batrachia) to the exclusion of caecilians (Duellman \& Trueb 1994, Milner 1988, Rage \& Janvier 1982, Trueb \& Cloutier 1991) (Figure 5A). Other morphology-based studies suggest that salamanders are the sistergroup of caecilians to the exclusion of frogs (Bolt 1991, Carroll 1995, Laurin 1998) (Figure 5B). Because all three lineages of extant amphibians acquired their distinctive body plans early in their evolutionary history, there are few reliable shared derived characters between them. Moreover, a rather poor Permian-Triassic fossil record complicates the determination of the evolutionary relationships among the Lissamphibia (Carroll 2000).

The first phylogenetic studies of this question used nuclear as well as mitochondrial rRNA data and suggested that caecilians are the closest living relatives of salamanders to the exclusion of frogs (Feller \& Hedges 1998, Hay et al. 1995, 





Hedges \& Maxson 1993, Hedges et al. 1990, Larson \& Wilson 1989) (Figure 5B). Phylogenetic analyses of complete mitochondrial genomes of a salamander (Mertensiella luschani), a caecilian (Typhlonectes natans), and a frog (Xenopus laevis) supported with high statistical support the Batrachia hypothesis (Zardoya \& Meyer 2001b) (Figure 5A). This latter result is in agreement with most morphological evidence rather than with earlier molecular studies. The Batrachia hypothesis is currently supported by both morphological and molecular analyses. Yet, more work on nuclear markers and the study of the largely unresolved intraordinal relationships of all three orders possibly also with more complete mitochondrial genomes are expected to settle this long-standing debate in the near future.

\section{AM NIOTE RELATION SHIPS WITH EMPHASIS ON THE RELATIONSHIPS OF TURTLES}

For more than 150 years, the phylogenetic relationships among major amniote lineages have been debated among evolutionary biologists. This phylogenetic problem remains difficult to solve partly because turtles have such a unique morphology and because only few characters can be used to link them with any other group of amniotes. Moreover, different traits provide conflicting phylogenetic signals. Historically, turtles have been considered the only living survivors of anapsid reptiles (those that lack temporal fenestrae in the skull), and the extinct procolophonids (Laurin \& Reisz 1995) or pareiasaurs their closest relatives (Gregory 1946; Lee 1995, 1996, 1997). The traditional hypotheses placed turtles (as part of the Anapsida) as sistergroup to all other living amniotes (Gaffney 1980).

More recent phylogenetic analyses based on morphological and fossil data agreed that synapsids - the mammals - (those with a single lower temporal hole in their skulls) are the sistergroup to the remaining amniotes, and they placed anapsids as sistergroup of the diapsids - tuatara, snakes and lizards, crocodiles and birds-(those that have, at least ancestrally, two fenestrae in the temporal region of the skull) (Gauthier et al. 1988, Laurin \& Reisz 1995, Lee 1997, Reisz 1997) (Figure 6A). However, during the past decade several different amniote phylogenies have been proposed by both paleontologists (Rieppel \& Reisz 1999) and molecular phylogeneticists (Zardoya \& Meyer 2001a), most of which favor a more derived position for turtles within the reptiles (Figures $6 B, C, D$ ).

Recent paleontological analyses reveal that the traditional assignment of turtles to the anapsids may be only weakly supported (deBraga \& Rieppel 1997, Rieppel \& deBraga 1996, Rieppel \& Reisz 1999). Alternatively, turtles have been suggested to be the closest living relatives of the Lepidosauria (tuatara and squamata, i.e., lizards and snakes) (Figure 6B) (deBraga \& Rieppel 1997, Rieppel \& deBraga 1996, Rieppel \& Reisz 1999), or the sistergroup of Archosauria (crocodiles and birds) (Figure 6C) (Hennig 1983). Both placements imply that the anapsid condition of the turtle skull is a secondary loss or reversal to an ancestral condition.

The first molecular phylogenetic analyses of this issue were based on complete $12 \mathrm{~S}$ and $16 \mathrm{~S}$ rRNA mitochondrial gene data sets. They supported a turtle + diapsid 




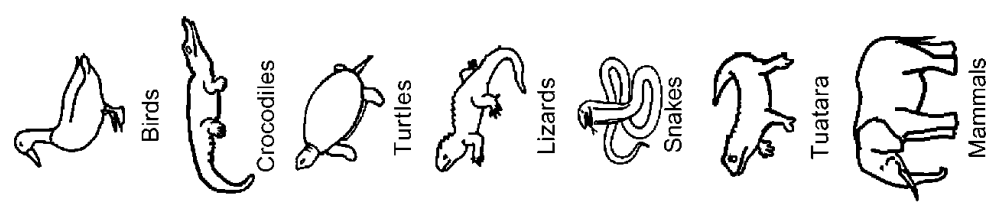

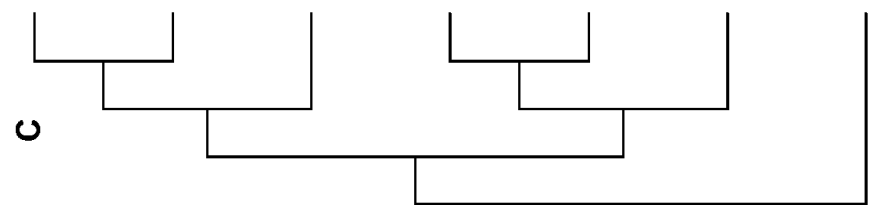

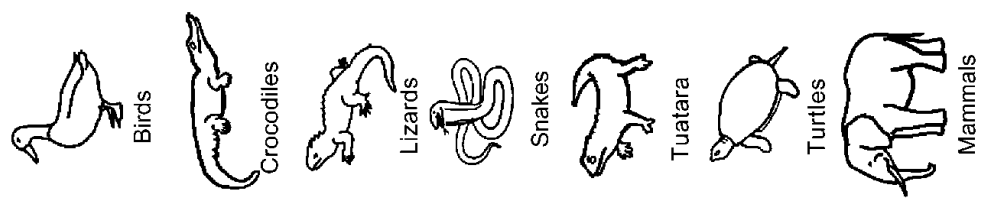





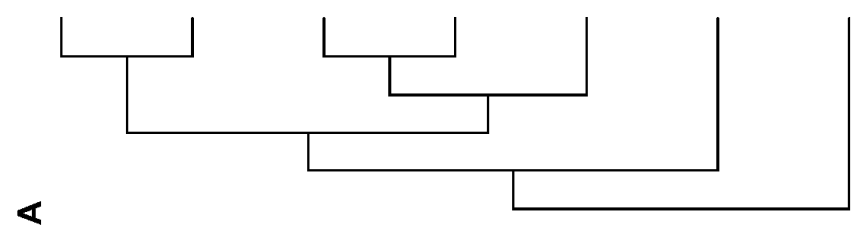


sistergroup relationship to the exclusion of mammals (Cao et al. 1998, Hedges 1994, Strimmer \& von Haeseler 1996) (Figure 6A). More recent reanalyses of the same genes with additional taxa (including representatives of the two major lineages of turtles, Pleurodira and Cryptodira) recover a turtle + Archosauria clade with moderately high bootstrap support (Zardoya \& Meyer 1998) (Figure 6C). However, two alternative hypotheses, turtles as anapsids (Figure 6A) or turtles as sistergroup of lepidosaurs (Figure $6 B$ ), could not be statistically rejected based on this data set (Zardoya \& Meyer 1998). Recent phylogenetic analyses of relatively large mitochondrial and nuclear sequence data sets further supported the diapsid affinities of turtles, and only differ on their relative position with respect to Lepidosauria and Archosauria. Molecular evidence based on complete mitochondrial protein-coding genes further confirmed the archosaurian affinities of turtles, and statistically rejected alternative hypotheses (Janke et al. 2001, Kumazawa \& Nishida 1999) (Figure 6C). Phylogenetic analyses of a data set including complete mitochondrial protein-coding, rRNA, and tRNA genes also strongly supported the phylogenetic position of turtles as the sistergroup of archosaurs (Zardoya \& Meyer 2001b) (Figure 6C). Recent phylogenetic analyses that included the tuatara complete mitochondrial genome firmly support the sistergroup relationship between tuatara and lizards + snakes, and a sistergroup relationship between turtles and archosaurs (Rest et al. 2003). In agreement with mitochondrial evidence, nuclear pancreatic polypeptide data support archosaurs as the living sistergroup of turtles (Platz \& Conlon 1997).

Phylogenetic analyses based on eleven nuclear proteins, in addition to the nuclear $18 \mathrm{~S}$ and $28 \mathrm{~S}$ rRNA genes, suggested that crocodiles are the closest living relatives of turtles (Hedges \& Poling 1999) to the exclusion of birds (Figure 6D). Furthermore, a phylogenetic analysis that combined mitochondrial and nuclear data also recovered a crocodile + turtle grouping (Cao et al. 2000). However, morphological data strongly support the monophyly of archosaurs (Gaffney 1980, Gauthier et al. 1988). It is important to note that both crocodiles and turtles show significantly long branches that might introduce biases into the phylogenetic analyses (Sanderson \& Shaffer 2002). Hence, the sistergroup relationship of crocodiles and turtles needs to be treated as tentative, and further molecular clarification is needed.

Both recent paleontological and molecular data agree on the more derived position of turtles as diapsids. This new placement of turtles (either as the sistergroup

Figure 6 The phylogenetic relationships of turtles to the other groups of living amniotes. (A) Turtles as the only living representatives of anapsid reptiles, and as the sistergroup of diapsid reptiles, i.e., the Lepidosauria (the tuatara, snakes, and lizards) + Archosauria (crocodiles and birds). (B) Turtles placed as diapsids, and as the sistergroup of the Lepidosauria. $(C)$ Turtles as diapsids, and as the sister group of the Archosauria. (D) Turtles as diapsids, placed inside the Archosauria, and as the sistergroup of crocodiles. Most recent molecular data favor either hypotheses $C$ or $D$. 
to Archosaurs, Lepidosaurs, or Crocodilia) has profound implications for the reconstruction of amniote evolution, including, but not limited to, the understanding of the evolution of the fenestration of the skull.

\section{PHYLOGENETIC RELATIONSHIPS OF BIRDS}

Ever since the discovery of Archaeopteryx, this fossil genus from the Upper Jurassic was recognized as one of the missing links between dinosaurs and birds (Huxley 1868). The sistergroup relationships between theropod dinosaurs (Saurischia) and birds is now firmly established (Ostrom 1975, Xu et al. 2003; but see Feduccia 1996). It is now generally believed by both morphologists and paleontologists that crocodiles are the closest living relatives of birds, and that both groups are the only surviving lineages of the Archosauria (e.g., Gaffney 1980, Gauthier et al. 1988). Most molecular studies based on mitochondrial (e.g., Cao et al. 2000, Hedges 1994, Mindell et al. 1999, Zardoya \& Meyer 1998) or nuclear (e.g., Caspers et al. 1996, Platz \& Conlon 1997) sequence data agree with this hypothesis. The only exception is the recent molecular work of Hedges and Poling (Hedges \& Poling 1999), which supported crocodiles + turtles as the closest living sistergroup of birds (but see above).

Most of the modifications in birds that are associated with powered flight (e.g., feathers, a fully opposable digit for perching, a keeled sternum, and a fused pygostyle that refines flight maneuverability) evolved within a short period of time (less than 10 million years) in the early Cretaceous (Sereno 1999). Adaptation to flight led to a rapid radiation and the origin of the orders of modern birds during the Late Cretaceous (Cooper \& Penny 1997; but see Feduccia 1996, 2003), a period in which the fossil record of modern birds is relatively poor (Feduccia 1996). As a result, the phylogenetic relationships of modern avian orders remain unresolved based on paleontological data. Traditionally, extant birds are classified based on the palatal structure into Palaeognathae and Neognathae (Pycraft 1900) (Figure 7A). The Palaeognathae include the Struthioniformes (ratites) and Tinamiformes (tinamous). Within the Neognathae, Anseriformes (ducks), Charadriiformes (shorebirds), Gaviiformes (loons), and Procellariiformes (albatrosses) are considered to have diverged early (Feduccia 1996, Mindell et al. 1999).

The classic study of Sibley \& Ahlquist (Sibley \& Ahlquist 1990) based on DNADNA hybridization distances from 1700 species of birds was the first to suggest the palaeognath-neognaths division using molecular data (Figure 7A). It was a surprise

Figure 7 Major hypotheses about the relationships among the main lineages of birds. (A) Basal split between the Palaeognathae (ratites and tinamou) and the Neognathae (the rest). (B) Passeriformes (perching birds) are paraphyletic, with oscine passerines (songbirds) as sistergroup of all other birds. Palaeognathae are suggested to be a derived rather than basal group as suggested by the traditional hypothesis $(A)$. Most recent molecular data favor hypothesis $A$. 

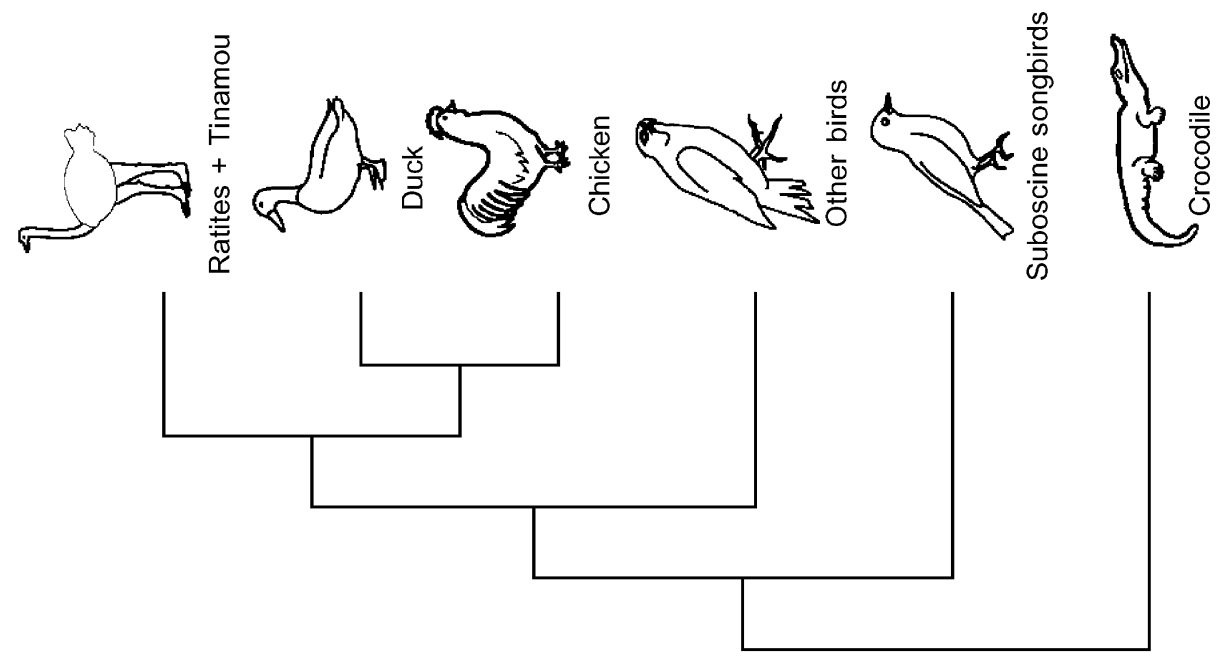

m
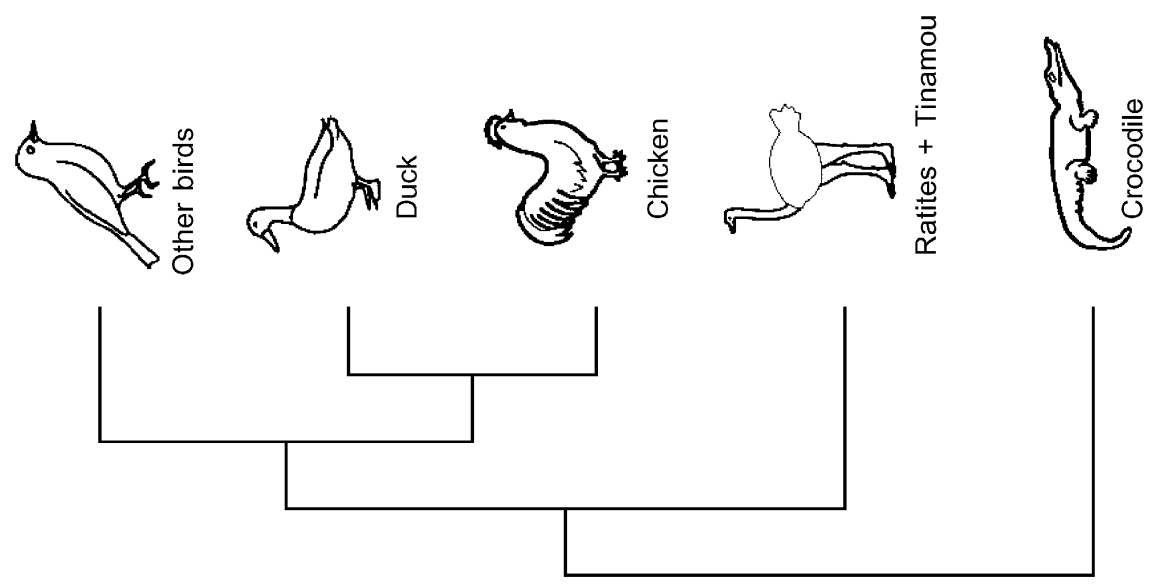

$\varangle$ 
that more recent work based on complete mitochondrial genome sequence data challenged this traditional view of a basal divergence between Palaeognathae and Neognathae (Härlid \& Arnason 1999, Mindell et al. 1999) (Figure 7B). In these mitochondrial phylogenies, Passeriformes (perching birds) are paraphyletic, with oscine passerines (songbirds) as the sistergroup of all other birds. Struthioniformes are suggested to be in a rather derived position as sistergroup of galliformes + anseriformes (Galloanserae). However, it has been suggested that these results are likely to be the result of insufficient taxon sampling (van Tuinen et al. 2000). A recent molecular phylogeny of representatives of all modern avian orders based on the complete mitochondrial $12 \mathrm{~S}$ and $16 \mathrm{~S}$ rRNA and nuclear $18 \mathrm{~S}$ genes recovered the basal split between palaeognathans and neognathans and placed Galloanserae as the most basal neognathans (van Tuinen et al. 2000) (Figure 7A). The traditional division between palaeognathans and neognathans was also achieved when the mitochondrial DNA data was corrected for rate heterogeneity (Paton et al. 2002). The same results were achieved based on the complete nuclear RAG-1 gene (Groth \& Barrowclough 1999). Furthermore, the monophyly of the Passeriformes is supported by several recent molecular studies that are based on nuclear DNA sequences (Barker et al. 2002). It would appear that mitochondrial DNA sequences provide somewhat less reliable phylogenetic information for the question on the ordinal relationships of birds and future studies might need to combine mitochondrial with new nuclear DNA markers to ascertain the relationships among the major ordinal lineages of the Class Aves.

\section{THE SISTERGROUP OF PLACENTAL MAMMALS}

The traditional view of the evolution of mammals based on both neontological, morphological, and fossil evidence identified the marsupials as the sistergroup of the eutherians (placental mammals) to the exclusion of the monotremes (the platypus and echidnas) (Carroll 1988) (Figure 8A). Many morphological features have been interpreted as shared derived characters between marsupials and placentals (Kermack \& Kermack 1984). However, a minority of researchers working on morphological characters advocate a sistergroup relationship of monotremes and marsupials (the Marsupionta hypothesis) based on similar tooth-replacement patterns (Gregory 1947, Kühne 1973), to the exclusion of placentals (Figure 8B). The relatively poor fossil record for monotremes (Carroll 1988) complicates the analysis of the phylogenetic relationships among these three living lineages of mammals.

The complete mitochondrial sequences of the platypus and the opossum were determined in an effort to address this debate (Figure 8) (Janke et al. 1994, 1996). Phylogenetic analyses of a data set that combined the inferred amino acid sequences of the mitochondrial protein-coding genes favored, with high statistical support, the monotreme + marsupial clade (Janke et al. 1996) (Figure 8B). Follow-up studies based on the same kind of data included the wallaroo, Macropus robustus (Janke et al. 2001), the wombat, Vombatus ursinus, and the echidna, 





Tachyglossus aculeatus (Janke et al. 2002) and confirmed the mitochondrial support for the Marsupionta hypothesis (Figure 8B). However, it has been noted that the strength of the support of the mitochondrial protein data set for the Marsupionta hypothesis varies considerably and depends on both the choice of outgroup and phylogenetic methods (Wadell et al. 1999). Moreover, considerable variation of pyrimidine (cytosine + thymine) frequencies between mammalian mitochondrial genomes seems to affect the recovery of deep divergences in the mammalian tree (Phillips \& Penny 2003). Phylogenetic analyses that correct for such bias support the Theria hypothesis (marsupials as sistergroup of placentals) (Phillips \& Penny 2003). DNA-DNA-hybridization analyses also supported the monotreme + marsupial clade (Kirsch \& Mayer 1998). The validity of these studies was questioned because both monotremes and marsupials show a relatively high GC content in comparison to the placentals (Kirsch \& Mayer 1998). Such a base-compositional bias could artificially group the monotremes and the marsupials together. Recently, a nuclear gene, the mannose 6-phosphate/insulin-like growth factor II receptor, was sequenced from representatives of all three mammalian groups in an attempt to clarify this issue (Killian et al. 2001). Phylogenetic analyses of this nuclear gene sequence data favored, with high statistical support, that marsupials are the sistergroup of eutherians to the exclusion of monotremes (Figure $8 A$ ). These nuclear data seem to corroborate the classical morphology-based hypothesis. Future molecular studies (including, e.g., more nuclear gene sequence data), will certainly improve our understanding of the sistergroup of placental mammals.

\section{CONCLUSIONSAND OUTLOOK}

Many of the major events that have occurred throughout the evolution of vertebrates are well documented in the fossil record. Vertebrates therefore offer the opportunity to study long-term evolutionary patterns and processes. However, some nodes, particularly often of those lineages related to the origin of the major clades in the vertebrate tree, remain controversial (Figure 1). This is probably because the origin of the main lineages of vertebrates was often accompanied by/caused by key morphological innovations and subsequent rapid diversification. Rapid origination of lineages, gaps in the fossil record associated with some of these events, and difficulties in the interpretation of synapomorphic character states that were overlaid by long periods of anagenetic changes, hamper the inference of the exact phylogenetic relationships. New vertebrate phylogenies based on molecular data are contributing to the resolution of many of the long-standing problems (Figure 9) (Zardoya et al. 2003). In most cases, molecular data corroborate morphological evidence, but in some cases molecular and morphological signals conflict. Besides the corroboration of many of the traditional morphology-based phylogenetic relationships, new molecular data sets have also been particularly helpful in discerning among competing hypotheses. Examples are (a) the now well-supported sistergroup relationships of lungfishes with tetrapods to the exclusion of coelacanths, $(b)$ the hypothesis that favors the Batrachia hypothesis (salamanders as 




Figure 9 Bayesian phylogeny of the major lineages of vertebrates based on the analysis of complete mitochondrial amino acid data sets (Zardoya et al. 2003). Numbers above branches are posterior probabilities. In this phylogeny the major polytomies of Figure 1 are shown as resolved. Agnathan sequences were not included in this analysis since the phylogenetic limits of mitochondrial genomes are exceeded at this level of phylogenetic inquiry. Note comments in the text for some issues regarding the use of mitochondrial DNA for some phylogenetic questions, e.g., monotreme-marsupial-eutherian relationships and the ordinal phylogeny among birds. 
sistergroup of frogs), and $(c)$ the placement of turtles as the sistergroup to Archosauria (Figure 9).

Occasionally, when conflicting topologies of molecular and morphological trees are obtained, doubt is raised about the validity of answers to problems that are considered to be settled. This is the case of the recent molecular evidence that supports a sistergroup relationship of hagfishes and lampreys against morphological evidence (Janvier 1996), or the mitochondrial support of a monotreme + marsupial clade against the seemingly well-established Theria hypothesis. Ultimately, comparisons of conflicting signals should enable evolutionary biologists to detect biases that result in misinterpreting one of the two types of data. Understanding the sources of signal conflict will definitively improve phylogenetic inference and may contribute to settling open debates in the systematic relationships among vertebrate lineages.

Two molecular markers, mitochondrial DNA and nuclear rRNA genes, have been widely, and by and large, successfully applied to phylogenetic inference of vertebrate relationships. Several recent advances in molecular techniques such as the development of new nuclear markers (Rag, c-mos, opsins, aquaporin, $\beta$-casein, enolase, and creatine kinase, among others) and the possibility of analyzing whole genomes are adding new important insights to the field of vertebrate molecular systematics. More efficient collection techniques for large molecular data sets are already having a major impact on the field. Moreover, more powerful and new phylogenetic algorithms [e.g., Bayesian, Markov Chain, Monte Carlo methods (Huelsenbeck et al. 2001); and the metapopulation genetic algorithm (Lemmon \& Milinkovitch 2002)] and alternative new approaches such as reconciled trees (Cotton \& Page 2002), as well as faster computers facilitate the estimation of phylogenetic relationships even when using large sequence data sets (Liu et al. 2001).

\section{ACKNOWLEDGMENTS}

We thank Brad Shaffer for insightful comments on an earlier version of the manuscript. This work received partial financial support from grants of the Deutsche Forschungsgemeinschaft, the VCI, and the University of Konstanz to A.M., and the Ministerio de Ciencia y Tecnología to R.Z. (REN2001-1514/GLO).

\section{The Annual Review of Ecology, Evolution, and Systematics is online at http://ecolsys.annualreviews.org}

\section{LITERATURE CITED}

Ahlberg PE, ed. 2001. Major Events in Early Vertebrate Evolution. Paleontology, Phylogeny, Genetics, and Development. London: Taylor \& Francis. 418 pp.

Ahlberg PE, Clack JA, Luksevics E. 1996. Rapid braincase evolution between Pan- derichthys and the earliest tetrapods. Nature 381:61-63

Ahlberg PE, Johanson Z. 1998. Osteolepiforms and the ancestry of tetrapods. Nature 395:792-94

Arratia G. 2001. The sister-group of Teleostei: 
consensus and disagreements. J. Vertebr. Paleontol. 21:767-73

Barker KF, Barrowclough GF, Groth JG. 2002. A phylogenetic hypothesis for passerine birds: taxonomic and biogeographic implications of an analysis of nuclear DNA sequence data. Proc. R. Soc. London Ser. B 269:295308

Benton MJ. 1990. Phylogeny of the major tetrapod groups: Morphological data and divergence dates. J. Mol. Evol. 30:409-24

Bjerring HC. 1985. Facts and thoughts on piscine phylogeny. In Evolutionary Biology of Primitive Fishes, ed. RE Foreman, A Gorbman, JM Dodd, R Olsson, pp. 31-57. New York: Plenum

Bolt JR. 1991. Lissamphibian origins. See Schultze \& Trueb 1991, pp. 194-222

Cao Y, Adachi J, Hasegawa M. 1998. Comment on the quartet puzzling method for finding maximum-likelihood tree topologies. Mol. Biol. Evol. 15:87-89

Cao Y, Sorenson MD, Kumazawa Y, Mindell DP, Hasegawa M. 2000. Phylogenetic position of turtles among amniotes: evidence from mitochondrial and nuclear genes. Gene 259:139-48

Carroll RL. 1988. Vertebrate Paleontology and Evolution. New York: Freeman

Carroll RL. 1995. Problems on the phylogenetic analysis of paleozoic choanates. Bull. Mus. Natl. Hist. Nat. Paris 4eme sér. 17:389-445

Carroll RL. 1997. Patterns and Processes of Vertebrate Evolution. Cambridge, UK: Cambridge Univ. Press

Carroll RL. 2000. The Lissamphibian enigma. See Heatwole \& Carroll 2000, pp. 127073

Caspers GJ, Reinders GJ, Leunissen JA, Watte J, de Jong WW. 1996. Protein sequences indicate that turtles branched off from the amniote tree after mammals. J. Mol. Evol. 42:580-86

Clack JA. 2002. Gaining Ground. Bloomington: Indiana Univ. Press

Clack JA. 2000. The origin of tetrapods. See Heatwole \& Carroll 2000, pp. 980-1029

Cloutier R, Ahlberg PE. 1996. Interrelation- ships of basal sarcopterygians. See Stiassny et al. 1996, pp. 445-79

Cooper A, Penny D. 1997. Mass survival of birds across the Cretaceous-tertiary boundary: molecular evidence. Science 275:110913

Cotton JA, Page RDM. 2002. Going nuclear: gene family evolution and vertebrate phylogeny reconciled. Proc. R. Soc. London Ser. B 269:1555-61

deBraga M, Rieppel O. 1997. Reptile phylogeny and the interrelationships of turtles. Zool. J. Linn. Soc. 120:281-354

Delarbre C, Escriva H, Gallut C, Barriel V, Kourilsky P, et al. 2000. The complete nucleotide sequence of the mitochondrial DNA of the agnathan Lampetrafluviatilis: bearings on the phylogeny of cyclostomes. Mol. Biol. Evol. 17:519-29

Duellman WE, Trueb L. 1994. Biology of Amphibians. Baltimore, MD: Johns Hopkins Univ. Press

Eschmeyer WN. 1998. Catalog of Fishes. San Francisco: Cal. Acad. Sci.

Feduccia A. 1996. The Origin and Evolution of Birds. New Haven, CT: Yale Univ. Press

Feduccia A. 2003. 'Big bang' for tertiary birds? Trends Ecol. Evol. 18:172-76

Feller AE, Hedges SB. 1998. Molecular evidence for the early history of living amphibians. Mol. Phylogenet. Evol. 9:50916

Gaffney ES. 1980. Phylogenetic relationship of the major groups of ammniotes. In The Terrestrial Enviroment and the Origin of the Land Vertebrates, ed. AL Panchen, pp. 593610. London: Academic

Gardiner BG, Maisey JG, Littlewood DT. 1996. Interrelationships of basal neopterygians. See Stiassny et al. 1996, pp. 117-46

Gardiner BG, Schaeffer B. 1989. Interrelationships of lower actinopterygian fishes. Zool. J. Linn. Soc. 97:135-87

Gauthier J, Kluge AG, Rowe T. 1988. Amniote phylogeny and the importance of fossils. Cladistics 4:105-209

Grande L, Bemis WE. 1996. Interrelationships of Acipenseriformes, with comments 
on "Chondrostei." See Stiassny et al. 1996, pp. $85-115$

Greenwood PH, Miles RS, Patterson C, eds. 1973. Interrelationships of Fishes. Zool. J. Linn. Soc. (Suppl. 1). 536 pp.

Greenwood PH, Rosen DE, Weitzman SH, Myers GS. 1966. Phyletic studies of teleostean fishes, with a provisional classification of living forms. Bull. Am. Mus. Nat. Hist. 131:339-456

Gregory WK. 1946. Pareiasaurs versus placodonts as near ancestors to turtles. Bull. Am. Mus. Nat. Hist. 86:275-326

Gregory WK. 1947. The monotremes and the palimpsest theory. Bull. Am. Mus. Nat. Hist. 88:1-52

Groth JG, Barrowclough GF. 1999. Basal divergences in birds and the phylogenetic utility of the nuclear RAG-1 gene. Mol. Phylogenet. Evol. 12:115-23

Härlid A, Arnason U. 1999. Analyses of mitochondrial DNA nest ratite birds within the Neoagnathae: supporting a neotenous origin of ratite morphological characters. Proc. $R$. Soc. London Ser. B 266:305-9

Hay JM, Ruvinsky I, Hedges SB, Maxson LR. 1995. Phylogenetic relationships of amphibian families inferred from DNA sequences of mitochondrial $12 \mathrm{~S}$ and $16 \mathrm{~S}$ ribosomal RNA genes. Mol. Biol. Evol. 12:928-37

Heatwole H, Caroll RL, eds. 2000. Amphibian Biology. Chipping Norton, Aust.: Surrey Beatty \& Sons. 1495 pp.

Hedges SB. 1994. Molecular evidence for the origin of birds. Proc. Natl. Acad. Sci. USA 91:2621-24

Hedges SB, Hass CA, Maxson LR. 1993. Relations of fish and tetrapods. Nature 363:501-2

Hedges SB, Maxson LR. 1993. A molecular perspective on lissamphibian phylogeny. Herpetol. Monogr. 7:27-42

Hedges SB, Moberg KD, Maxson LR. 1990. Tetrapod phylogeny inferred from $18 \mathrm{~S}$ and $28 \mathrm{~S}$ ribosomal RNA sequences and a review of the evidence for amniote relationships. Mol. Biol. Evol. 7:607-33

Hedges SB, Poling LL. 1999. A molecular phylogeny of reptiles. Science 283:998-1001
Hennig W. 1983. Testudines. In Stammesgeschichte der Chordaten, ed. W Hennig, pp. 132-39. Hamburg: Parey. 208 pp.

Huelsenbeck JP, Ronquist FR, Nielsen R, Bollback JP. 2001. Bayesian inference of phylogeny and its impact on evolutionary biology. Science 294:2310-14

Huxley TH. 1861. Preliminary essay upon the systematic arrangement of the fishes of the Devonian epoch. Figures and descriptions illustrative of British organic remains. Mem. Geol. Surv. UK 10:1-40

Huxley TH. 1868. On the animals which are most nearly intermediate between the birds and reptiles. Ann. Mag. Nat. Hist. 4:66-75

Inoue JG, Miya M, Tsukamoto K, Nishida M. 2003. Basal actinopterygian relationships: a mitogenomic perspective on the phylogeny of the "ancient fish." Mol. Phylogenet. Evol. 26:110-20

Janke A, Erpenbeck D, Nilsson M, Arnason U. 2001. The mitochondrial genomes of the iguana (Iguana iguana) and the caiman (Caiman crocodylus): implications for amniote phylogeny. Proc. R. Soc. London Ser. B 268:623-31

Janke A, Feldmaier-Fuchs G, Thomas K, von Haeseler A, Pääbo S. 1994. The marsupial mitochondrial genome and the evolution of placental mammals. Genetics 137:243-56

Janke A, Gemmell NJ, Feldmaier-Fuchs G, von Haeseler A, Paabo S. 1996. The mitochondrial genome of a monotreme-the platypus (Ornithorhynchus anatinus). J. Mol. Evol. 42:153-59

Janke A, Magnell O, Wieczorek G, Westerman M, Arnason U. 2002. Phylogenetic analyses of 18S rRNA and the mitochondrial genomes of the Wombat, Vombatus ursinus, and the spiny anteater, Tachyglossus aculeatus: increased support for the Marsupionta hypothesis. J. Mol. Evol. 54:71-80

Janvier P. 1981. The phylogeny of the Craniata with particular reference to the significance of fossil "agnathans". J. Vertebr. Paleontol. 1:121-59

Janvier P. 1996. Early Vertebrates. Oxford, UK: Oxford Univ. Press 
Jessen HL. 1973. Interrelationships of actinopterygians and brachiopterygians: evidence from pectoral anatomy. See Greenwood et al. 1973, pp. 227-232

Kermack DM, Kermack KA. 1984. The Evolution of Mammalian Characters. London: Croom Helm

Killian JK, Buckley TR, Stewart N, Munday BL, Jirtle RL. 2001. Marsupials and Eutherians reunited: genetic evidence for the Theria hypothesis of mammalian evolution. Mamm. Genome 12:513-17

Kirsch JAW, Mayer GC. 1998. The platypus is not a rodent: DNA hybridization, amniote phylogeny and the palimpsest theory. Philos. Trans. R. Soc. London Ser. B 353:1221-37

Kühne WG. 1973. The systematic position of monotremes reconsidered (Mammalia). $Z$. Morph. Tiere 75:59-64

Kumazawa Y, Nishida M. 1999. Complete mitochondrial DNA sequences of the green turtle and blue-tailed mole skink: statistical evidence for archosaurian affinity of turtles. Mol. Biol. Evol. 16:784-92

Kuraku S, Hoshiyama D, Katoh K, Suga H, Miyata T. 1999. Monophyly of lampreys and hagfishes supported by nuclear DNA-coded genes. J. Mol. Evol. 49:729-35

Larson A, Wilson AC. 1989. Patterns of ribosomal RNA evolution in salamanders. Mol. Biol. Evol. 6:131-54

Lauder GV, Liem KF. 1983. The evolution and interrelationships of the actinopterygian fishes. Bull. Mus. Comp. Zool. 150:95197

Laurin M. 1998. The importance of global parsimony and historical bias in understanding tetrapod evolution. Part I. Systematics, middle ear evolution and jaw suspension. Ann. Sci. Nat. 19:1-42

Laurin M, Reisz RR. 1997. A new perspective on tetrapod phylogeny. In Amniote Origins: Completing the Transition to Land, ed. SS Sumida, KL Martin, pp. 9-59. New York: Academic. 400 pp.

Laurin M, Reisz RR. 1995. A reevaluation of early amniote phylogeny. Zool. J. Linn. Soc. 113:165-223
Le HL, Lecointre G, Perasso R. 1993. A 28S rRNA-based phylogeny of the Gnathostomes: first steps in the analysis of conflict and congruence with morphologically based cladograms. Mol. Phylogenet. Evol. 2:31-51

Lee MSY. 1995. Historical burden in systematics and the interrelationships of 'parareptiles'. Biol. Rev. 70:459-547

Lee MSY. 1996. Correlated progression and the origin of turtles. Nature 379:812-15

Lee MSY. 1997. Pareiasaur phylogeny and the origin of turtles. Zool. J. Linn. Soc. 120:197280

Lemmon A, Milinkovitch MC. 2002. The metapopulation genetic algorithm: an efficient solution for the problem of large phylogeny estimation. Proc. Natl. Acad. Sci. USA 99:10516-21

Liu FR, Miyamoto MM, Freire MP, Ong PQ, Tennant MR, et al. 2001. Molecular and morphological supertrees for eutherian (Placental) mammals. Science 291:1786-89

Mallat J, Sullivan J. 1998. 28S and 18S rDNA sequences support the monophyly of lampreys and hagfishes. Mol. Biol. Evol. 15:1706-18

Mallat J, Sullivan J, Winchell CJ. 2001. The relationship of lampreys to hagfishes: a spectral analysis of ribosomal DNA sequences. See Ahlberg 2001, pp. 106-18

Meyer A. 1995. Molecular evidence on the origin of tetrapods and the relationships of the coelacanth. Trends Ecol. Evol. 10:11116

Meyer A, Wilson AC. 1990. Origin of tetrapods inferred from their mitochondrial DNA affiliation to lungfish. J. Mol. Evol. 31:35964

Milner AR. 1988. The relationships and origin of living amphibians. In The Phylogeny and Classification of the Tetrapods, Vol. 1: Amphibians, Reptiles, Birds, ed. MJ Benton, pp. 59-102. Oxford, UK: Clarendon. 392 pp.

Mindell DP, Sorenson MD, Dimcheff DE, Hasegawa M, Ast JC, Yuri T. 1999. Interordinal relationships of birds and other reptiles based on whole mitochondrial genomes. Syst. Biol. 48:138-52 
Miya $M$, Takeshima $H$, Endo $H$, Ishiguro NB, Inoue JG, et al. 2003. Major patterns of higher teleostean phylogenies: a new perspective based on 100 complete mitochondrial sequences. Mol. Phylogenet. Evol. 26:121-38

Nelson GJ. 1989. Phylogeny of major fish groups. In The Hierarchy of Life, ed. B Fernholm, K Bremer, H Jörnvall, pp. 325-36. Amsterdam: Elsevier. 488 pp.

Nelson GJ. 1969. Gill arches and the phylogeny of fishes, with notes on the classification of vertebrates. Bull. Am. Mus. Nat. Hist. 141:475-552

Nelson GJ. 1994. Fishes of the World. New York: Wiley

Noack K, Zardoya R, Meyer A. 1996. The complete mitochondrial DNA sequence of the bichir (Polypterus ornatipinnis), a basal ray-finned fish: ancient establishment of the consensus vertebrate gene order. Genetics 144:1165-80

Olsen PE. 1984. The skull and pectoral girdle of the parasemiontid fish Watsonulus eugnathoides from the early Triassic Sakanema group of Madagascar, with comments on the relationships of the holostean fishes. $J$. Vertebr. Paleontol. 4:481-99

Ostrom JH. 1975. The origin of birds. Annu. Rev. Earth Planet. Sci. 3:55-77

Panchen AL, Smithson TR. 1987. Character diagnosis, fossils and the origin of tetrapods. Biol. Rev. 62:341-438

Parsons TS, Williams EE. 1963. The relationships of the modern Amphibia: a reexamination. Q. Rev. Biol. 38:26-53

Paton T, Haddrath O, Baker AJ. 2002. Complete mitochondrial DNA genome sequences show that modern birds are not descended from transitional shorebirds. Proc. R. Soc. London Ser. B 269:839-46

Patterson C. 1973. Interrelationships of holosteans. See Greenwood et al. 1973, pp. 233305

Phillips MJ, Penny D. 2003. The root of the mammalian tree inferred from complete mitochondrial genomes. Mol. Phylogenet. Evol. In press
Platz JE, Conlon JM. 1997. Reptile relationships turn turtle and turn back again. Nature 389:246

Pycraft WP. 1900. The morphology and phylogeny of the Palaeognathae (Ratitae and Crypturi) and the Neognathae (Carinatae). Trans. Zool. Soc. London 15:149290

Rage JC, Janvier P. 1982. Le probleme de la monophylie des amphibiens actuels, a la lumiere des nouvelles donnees sur les affinites des tretapodes. Geobios 6:65-83

Rasmussen AS, Arnason U. 1999. Molecular studies suggest that cartilagionous fishes have a terminal position in the piscine tree. Proc. Natl. Acad. Sci. USA 96:217782

Rasmussen AS, Janke A, Arnason A. 1998. The mitochondrial DNA molecule of the hagfish (Myxine glutionosa) and vertebrate phylogeny. J. Mol. Evol. 46:382-88

Reisz RR. 1997. The origin and early evolutionary history of amniotes. Trends Ecol. Evol. 12:218-22

Rest JS, Ast JC, Austin CC, Waddell PJ, Tibbetts EA, et al. 2003. Molecular systematics of primary reptilian lineages and the tuatara mitochondrial genome. Mol. Phylogenet. Evol. In press

Rieppel O, deBraga M. 1996. Turtles as diapsid reptiles. Nature 384:453-55

Rieppel O, Reisz RR. 1999. The origin and early evolution of turtles. Annu. Rev. Ecol. Syst. 30:1-22

Sanderson MJ, Shaffer HB. 2002. Troubleshooting molecular phylogenetic analyses. Annu. Rev. Ecol. Syst. 33:49-72

Schultze HP, Cumbaa SL. 2001. Dialipina and the characters of basal actinopterygians. See Ahlberg 2001, pp. 315-32

Schultze L, Trueb L, eds. 1991. Origins of the Major Groups of Tetrapods: Controversies and Consensus. Ithaca: Cornell Univ. Press. $724 \mathrm{pp}$.

Sereno PC. 1999. The evolution of dinosaurs. Science 2137-47

Shu DG, Conway Morris S, Han J, Zhang ZF, Yasui K, et al. 2003. Head and backbone of 
the early cambrian vertebrate Haikouichthys. Nature 421:526-29

Shu DG, Luo HL, Morris SC, Zhang XL, Hus SX, et al. 1999. Lower Cambrian vertebrates from south China. Nature 402:4246

Sibley CG, Ahlquist JE. 1990. Phylogeny and Classification of Birds: A Study in Molecular Evolution. New Haven, CT: Yale Univ. Press

Stiassny MLJ, Parent LR, Johnson GD, eds. 1996. Interrelationships of Fishes. San Diego, CA: Academic. 496 pp.

Strimmer K, von Haeseler A. 1996. Quartet puzzling: a quartet maximum-likelihood method for reconstructing tree topologies. Mol. Biol. Evol. 13:964-69

Szarski H. 1962. The origin of the Amphibia. Q. Rev. Biol. 37:189-241

Takezaki N, Figueroa F, Zaleska-Rutczynska Z, Klein J. 2003. Moleular phylogeny of early vertebrates: monophyly of the agnathans as revealed by sequences of 35 genes. Mol. Biol. Evol. 20:287-92

Takezaki N, Gojobori T. 1999. Correct and incorrect vertebrate phylogenies obtained by the entire mitochondrial DNA sequences. Mol. Biol. Evol. 16:590-601

Tohyama Y, Ichimiya T, Kasama-Yoshida H, Cao Y, Hasegawa M, et al. 2000. Phylogenetic relation of lungfish indicated by the amino acid sequence of myelin DM20. Brain Res. Mol. Brain Res. 80:256-59

Trueb L, Cloutier R. 1991. A phylogenetic investigation of the inter- and intrarelationships of the Lissamphibia (Amphibia: Temnospondyli). See Schultze \& Trueb 1991, pp. 223-313

van Tuinen M, Sibley CG, Hedges SB. 2000. The early history of modern birds inferred from DNA sequences of nuclear and mitochondrial ribosomal genes. Mol. Biol. Evol. 17:451-57

Venkatesh B, Erdmann MV, Brenner S. 2001. Molecular synapomorphies resolve evolutionary relationships of extant jawed vertebrates. Proc. Natl. Acad. Sci. USA 98:1138287

Vorobyeva E, Schultze HP. 1991. Description and systematics of panderichthyid fishes with comments on their relationship to tetrapods. See Schultze \& Trueb 1991, pp. 68109

Wadell PJ, Cao Y, Hauf J, Hasegawa M. 1999. Using novel phylogenetic methods to evaluate mammailan mtDNA, including amino acid-invariant sites-LogDet plus site stripping, to detect internal conflicts in the data, with special reference to the positions of the hedgehog, armadillo, and elephant. Syst. Biol. 48:31-53

Xu X, Zhou ZH, Wang XL, Kuang XW, Zhang FC, Du XK. 2003. Four-winged dinosaurs from China. Nature 421:335-40

Zardoya R, Cao Y, Hasegawa M, Meyer A. 1998. Searching for the closest living relative(s) of tetrapods through evolutionary analyses of mitochondrial and nuclear data. Mol. Biol. Evol. 15:506-17

Zardoya R, Malaga-Trillo E, Veith M, Meyer A. 2003. Complete nucleotide sequence of the mitochondrial genome of a salamander, Mertensiella luschani. Gene. In press

Zardoya R, Meyer A. 1996. Evolutionary relationships of the coelacanth, lungfishes, and tetrapods based on the 28S ribosomal RNA gene. Proc. Natl. Acad. Sci. USA 93:544954

Zardoya R, Meyer A. 1997a. The complete DNA sequence of the mitochondrial genome of a "living fossil", the coelacanth (Latimeria chalumnae). Genetics 146:995-1010

Zardoya R, Meyer A. 1997b. Molecular phylogenetic information on the identity of the closest living relative(s) of land vertebrates. Naturwissenschaften 84:389-97

Zardoya R, Meyer A. 1998. Complete mitochondrial genome suggests diapsid affinities of turtles. Proc. Natl. Acad. Sci. USA 95:14226-31

Zardoya R, Meyer A. 2001a. The evolutionary position of turtles revised. Naturwissenschaften 88:193-200

Zardoya R, Meyer A. 2001b. On the origin of and phylogenetic relationships among living amphibians. Proc. Natl. Acad. Sci. USA 98:7380-83 
Zardoya R, Meyer A. 2001c. Vertebrate phylogeny: limits of inference of mitochondrial genome and nuclear rDNA squence data due to an adverse phylogenetic signal/noise ratio. See Ahlberg 2001, pp. 106-18
Zharkikh A, Li WH. 1992. Statistical properties of bootstrap estimation of phylogenetic variability from nucleotide sequences: I. Four taxa with a molecular clock. Mol. Biol. Evol. 9:1119-47 